\title{
ANGKA ASAM DAN PEROKSIDA MINYAK JELANTAH DARI PENGGORENGAN LELE SECARA BERULANG
}

\author{
Zulfa Khoirunnisa ${ }^{1}$, Agung Setya Wardana ${ }^{2}$, Rusdin Rauf ${ }^{3 *}$ \\ ${ }^{1,3}$ Program Studi Ilmu Gizi, Fakultas Ilmu Kesehatan, Universitas \\ Muhammadiyah Surakarta. \\ Jl. Ahmad Yani, Kartasura, Surakarta 57169, Jawa Tengah, Indonesia \\ Email: ${ }^{1}$ zulfakhorunnisa@ gmail.com; ${ }^{3}$ rusdin.rauf@ums.ac.id \\ ${ }^{2}$ Program Studi Ilmu Gizi, Institut Teknologi Sains dan Kesehatan PKU \\ Muhammadiyah Surakarta, Jawa tengah, Indonesia \\ Email : ${ }^{3}$ agungwardana@gmail.com
}

Tanggal Submisi: 19 November 2019; Tanggal Penerimaan: 30 Desember 2019

\begin{abstract}
ABSTRAK
Minyak goreng merupakan bahan pangan yang banyak dikonsumsi masyarakat. Penggunaan minyak goreng berulang kali akan mengakibatkan kerusakan minyak yang terdiri dari kerusakan oksidasi dan hidrolisis. Lele menjadi makanan yang sangat diminati oleh masyarakat Indonesia karena rasanya enak dan harganya juga relatif murah. Tujuan penelitian ini adalah untuk mengetahui angka asam dan peroksida minyak jelantah dari penggorengan lele secara berulang. Metode Penelitian ini adalah sampel diperoleh dari minyak goreng yang telah digunakan untuk menggoreng lele sebanyak tiga kali pada hari pertama dilanjutkan tiga kali pada hari kedua sehingga menjadi enam kali dan dilanjutkan tiga kali pada hari ketiga sehingga menjadi sembilan kali dengan ketentuan setiap menggoreng terdapat 3 ekor lele. Lele yang digunakan yaitu lele dengan berat 100-120 gram dengan penambahan bumbu. Deep frying merupakan metode penggorengan yang digunakan. Cara penggorengan diawali dengan memanaskan minyak goreng hingga mencapai suhu $150-165^{\circ} \mathrm{C}$. Sampel diambil sebanyak 50 gram setelah dilakukan penggorengan dan dimasukkan kedalam botol kaca kemudian disimpan dalam suhu kulkas untuk dianalisis angka asam dan angka peroksida. Seluruh jumlah angka asam dan angka peroksida pada penggorengan hari pertama hingga penggorengan hari ketiga masih dalam batas standar SNI 3741:2013 yang telah ditentukan.
\end{abstract}

Kata Kunci: Angka Asam, Angka Peroksida, Lele, Minyak Goreng, SNI.

ISSN 1979-7621 (Print). ISSN 2620-7761 (Online). 


\begin{abstract}
Cooking oil is a food that is consumed by many people. Repeated use of cooking oil can cause oil damage, namely oxidation, and hydrolysis. Catfish is a food that is very popular with the people of Indonesia because it tastes good, and the price is also relatively low. The purpose of this study was to determine the number of used cooking oil acid and peroxide from frying catfish.The sample of the research was obtained from cooking oil which has been used for frying catfish three times on the first day followed three times on the second day so that it becomes six times and continued three times on the third day so that it becomes nine times provided that each frying is 3 catfish tail. Catfish used were weighing 100-120 grams with the addition of seasoning. Deep frying was a frying method that begins by heating the oil until a temperature of $150-165^{\circ} \mathrm{C}$. A sample of 50 grams of cooking oil was taken into a glass bottle and then stored in a refrigerator until further analysis. The results showed that the increase in acid number and peroxide number was influenced by frying frequency. The more frying frequencies, the higher the value of the titrable acidity, and the peroxide of cooking oil.The recommendation is to research with a frequency of more than eight times, with other parameters.
\end{abstract}

Keywords : triable acidity, Peroxide, Catfish, Cooking oil.

\section{PENDAHULUAN}

Minyak goreng merupakan media penggorengan bahan pangan yang banyak dikonsumsi masyarakat luas. Data menunjukkan bahwa negara dengan penghasil minyak kelapa sawit terbesar di dunia yaitu Indonesia, luas area perkebunan kelapa sawit pada tahun 2012 seluas 9.074.621 hektar (Ditjenbun, 2014).

Penggunaan minyak goreng berulang kali akan mengakibatkan kerusakan minyak. Berbagai macam reaksi yang terjadi selama proses penggorengan seperti reaksi oksidasi, hidrolisis, polimerisasi, dan reaksi dengan logam dapat mengakibatkan minyak menjadi rusak. Proses kerusakan minyak berlangsung selama proses penggorengan. Kerusakan minyak selama proses penggorengan akan mempengaruhi mutu dan nilai gizi dari bahan pangan yang digoreng. Kerusakan minyak yang utama adalah karena peristiwa oksidasi, hasil yang diakibatkan salah satunya adalah terbentuknya peroksida dan aldehid (Sudarmadji dkk., 2007).

Salah satu fenomena yang dihadapi dalam proses penggorengan adalah menurunnya kualitas minyak setelah digunakan secara berulang pada suhu yang relatif tinggi $\left(160-180^{\circ} \mathrm{C}\right)$. Paparan oksigen dan suhu tinggi pada minyak goreng akan memicu terjadinya reaksi oksidasi (Aminah, 2010).

Lele merupakan salah satu produk makanan yang sudah popular di masyarakat Indonesia. Sejak dulu, masyarakat Indonesia terbiasa mengkonsumsi lele sebagai lauk pendamping nasi. Lele menjadi makanan yang sangat diminati oleh masyarakat Indonesia karena rasanya enak dan harganya juga relatif murah. Kandungan 
gizinya yang tinggi terutama protein, dagingnya yang halus, durinya teratur, dapat disajikan dalam berbagai olahan, rendah kolesterol dan menjadikan lele favorit dikalangan masyarakat dari kelas bawah, menengah dan atas ( Hendriana, 2010).

Jawa Tengah termasuk dalam 7 Provinsi terbesar penghasil lele di Indonesia bahkan menduduki peringkat ke dua setelah Jawa Barat. Produksi lele di jawa tengah mencapai 28.290 ton pada tahun 2009. Sentra budidaya lele di Jawa Tengah adalah kabupaten Demak, Purbalingga, Sukoharjo, Kudus, Karanganyar, Boyolali dan Banyumas (KKP, 2012).

$$
\text { Laelia dan Kurnia }
$$
melakukan penelitian mengenai pengaruh frekuensi penggorengan terhadap angka asam dan peroksida pada berbagai jenis minyak dengan produk ikan asin. Penelitian ini berbeda dengan penelitian yang sebelumnya karena produk yang digunakan berbeda dan pada penelitian ini hanya menggunakan satu jenis minyak goreng yaitu minyak goreng kelapa sawit sedangkan penelitian sebelumnya menggunakan berbagai jenis minyak yang terdiri dari minyak kelapa, minyak sawit dan minyak jagung.

Makanan yang digoreng menggunakan minyak yang berulang akan mempengaruhi kualitas makanan baik dari tekstur, rasa dan warna. Oleh karena itu minyak yang digunakan untuk menggoreng berulang perlu dilihat kualitasnya. Uji kualitas minyak dapat ditentukan dengan angka asam dan peroksida. Angka asam adalah banyaknya asam yang dapat dinetralkan dengan basa. Bilangan asam dipergunakan untuk mengukur jumlah asam lemak bebas yang terdapat dalam minyak. Penentuannya dapat dilakukan dengan metode titrasi. Asam lemak yang lepas dari gliserol disebut sebagai asam lemak bebas (Rauf, 2015).
Angka peroksida adalah nilai terpenting untuk menentukan derajat kerusakan pada minyak atau lemak. Asam lemak tidak jenuh dapat mengikat oksigen pada ikatan rangkapnya sehingga membentuk peroksida. Peroksida ini dapat ditentukan dengan metode iodometri. Bilangan peroksida menunjukkan terjadinya oksidasi dari minyak. Bilangan peroksida berguna untuk penentuan kualitas minyak setelah pengolahan dan penyimpanan. Peroksida akan meningkat sampai pada tingkat tertentu selama penyimpanan sebelum penggunaan, yang jumlahnya tergantung pada waktu, suhu, dan kontaknya dengan cahaya dan udara. Tingginya bilangan peroksida menandakan oksidasi yang berkelanjutan, tetapi rendahnya bilangan peroksida bukan berarti bebas dari oksidasi. Pada suhu penggorengan, peroksida meningkat, tetapi menguap dan meninggalkan sistem penggorengan pada temperatur yang tinggi (Raharjo, 2006).

Ikan lele memiliki kandungan gizi yang penting bagi tubuh kita, sehingga dapat dijadikan sebagai sumber pangan dan sebagai komoditas rumah tangga dalam meningkatkan perekonomian keluarga. Ikan lele kemudian dibudidayakan oleh manusia. Melihat kandungan gizi yang terdapat pada ikan lele, maka peminat ikan lele pun sangat banyak. Hampir semua lapisan masyarakat dapat merasakan nikmatnya ikan lele sebagai pelengkap hidangan (Saparinto, 2013).

Indonesia mengenal berbagai jenis lele, diantaranya lele lokal, lele dumbo, lele phiton dan lele babon (lele Kalimantan). Namun kebanyakan yang dibudidayakan hanya lele lokal (Clarias batarachus) dan lele dumbo (Clarias gaeriepinus). Kandungan gizi ikan lele dapat dilihat pada Tabel 1. 
Tabel 1. Kandungan Gizi Ikan Lele

\begin{tabular}{lc}
\multicolumn{2}{c}{ Per 100 gram } \\
\hline \multicolumn{1}{c}{ Zat Gizi } & Jumlah \\
\hline Energi (kkal) & 113 \\
Protein (g) & 17 \\
Lemak $(\mathrm{g})$ & 4,5 \\
Kalsium (mg) & 20 \\
Fosfor $(\mathrm{mg})$ & 200 \\
Besi $(\mathrm{mg})$ & 1,6 \\
Vitamin A (mg) & 150 \\
Vitamin B (mg) & 0,05 \\
Air (mg) & 76 \\
\hline
\end{tabular}

Sumber: DKBM (2010)

Minyak merupakan medium penggoreng bahan pangan yang banyak dikonsumsi masyarakat secara luas. Minyak kelapa sawit mengandung asam lemak jenuh dan asam lemak tak jenuh. Asam lemak yang rantai hidrokarbonnya terdapat ikatan rangkap disebut asam lemak tidak jenuh dan apabila tidak terdapat ikatan rangkap pada rantai hidrokarbonnya disebut asam lemak jenuh. Asam palmitat dan asam oleat merupakan asam lemak yang dominan dalam minyak sawit, sedangkan asam lemak linoleat dan asam stearatnya sedikit. Asam palmitat merupakan asam lemak jenuh rantai panjang yang memiliki titik cair (meelting point) yang tinggi yaitu $64^{\circ} \mathrm{C}$. Asam palmitat yang tinggi membuat minyak sawit lebih tahan terhadap oksidasi (ketengikan) dibanding jenis minyak lain. Titik cair asam palmitat yaitu $14^{\circ} \mathrm{C}$ (Zulkifli, 2014).

Pada umumnya sistem menggoreng bahan pangan ada 2 macam sistem yaitu salah satunya adalah penggorengan Deep Frying. Pada proses penggorengan ini bahan pangan terendam dalam minyak dan menggunakan suhu minyak mencapai $150-165^{\circ} \mathrm{C}$. Minyak yang digunakan dalam proses penggorengan Deep Frying umumnya menggunakan minyak nabati yang mengalami proses hidrogenasi dan bermutu tinggi (Ketaren, 2012).

Menurut Rauf (2015), reaksi kerusakan minyak dibedakan menjadi dua jenis reaksi yaitu reaksi oksidasi atau kerusakan oksidatif dan reaksi hidrolisis yang biasa disebut sebagai kerusakan hidrolitik. Produk reaksi oksidasi asam lemak tak jenuh yang dapat dijadikan indikator tingkat oksidasi adalah senyawa peroksida dan aldehid (Rauf, 2015). Reaksi oksidasi dimulai dengan pembentukan angka peroksida dan hidroperoksida. Selanjutnya asam-asam lemak akan terurai disertai dengan konversi hidroperoksida menjadi aldehida dan keton serta asam-asam lemak bebas (Ketaren, 2005). Proses oksidasi berlangsung dengan terabstraksinya ion hidrogen dari asam lemak bebas yang terkandung di dalam minyak. Ikatan tersebut akan digantikan dengan oksigen dan membentuk senyawa alkil radikal, yang kemudian bereaksi lebih lanjut menjadi senyawa peroksida radikal. Hal tersebut dapat ditunjukkan dengan munculnya bilangan peroksida dalam minyak.

Peroksida terbentuk pada tahap inisiasi (Ericson, 2002). Pada tahap ini, adanya panas atau cahaya akan melepas atom hidrogen dari asam lemak yang dikembangkan dengan $\mathrm{RH}$, membentuk radkal alkil bebas ( $\mathrm{R}^{\prime}$ ) dan radikal hidrogen (H'). Oksigen selanjutnya bereaksi dengan radikal alkil membentuk radikal peroksil (Rauf, 2015). Adapun reaksi inisiasi oksidasi tersebut dapat dilihat pada Gambar 1.

$$
\begin{aligned}
& \mathrm{RH} \quad \longrightarrow \quad \mathrm{R}^{\prime}+\mathrm{H}^{\prime} \\
& \mathrm{R}^{\prime}+\mathrm{O}_{2} \rightarrow \quad \text { ROO' } \\
& \begin{array}{c}
\text { Gambar 1. Reaksi inisiasi oksidasi } \\
\text { minyak (Rauf, 2015) }
\end{array}
\end{aligned}
$$

Reaksi hidrolisis terjadi pada minyak atau trigliserida yang disebabkan oleh adanya air dan aktivitas enzim lipase. Minyak yang dipanaskan mengalami hidrolisis yang diinisiasi oleh air dan uap air, secara bertahap menghasilkan digliserida dan monogliserida. Terbebasnya asam lemak dari gliserol 
menjadi petunjuk dalam menganalisis tingkat kerusakan hidrolitik, yaitu melalui analisis angka asam (Rauf, 2015). Adapun reaksi hidrolisis dapat dilihat pada Gambar 2.
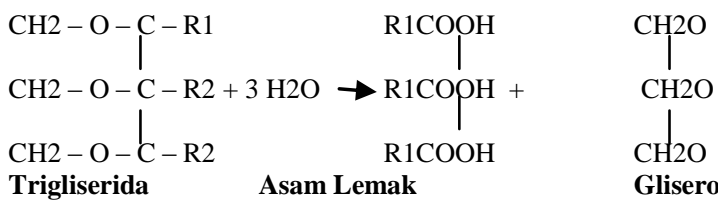

Gambar 2. Reaksi hidrolisis minyak (Herlina dan Ginting., 2002)

Reaksi hidrolisis yang terjadi pada minyak disebabkan oleh adanya air dan aktivitas enzim lipase (Rauf. 2015). Menurut Ketaren (2005), reaksi hidrolisis dapat terjadi pada proses penggorengan suhu tinggi. Bahan pangan yang digoreng akan menghasilkan air dan uap air. Air dan uap air akan menghidrolisis trigliserida pada suhu tinggi sehingga menghasilkan monogliserida, digliserida, gliserol, dan asam lemak bebas. Reaksi ini akan mengakibatkan ketengikan hidrolisa yang menghasilkan flavor dan bau tengik pada minyak tersebut.

Salah satu parameter penentu kualitas minyak goreng yaitu besarnya kandungan kadar asam lemak bebas didalam minyak tersebut. Angka asam yang tinggi mengartikan bahwa asam lemak bebas dalam minyak juga tinggi sehingga dapat disimpulkan kualitas minyak rendah (Winarno, 2004).

Permasalahan penelitian atau hipotesa penelitian ini yaitu ada pengaruh frekuensi penggorengan terhadap angka asam dan peroksida minyak jelantah hasil penggorengan lele.

\section{METODE PENELITIAN}

Alat dan Pembuatan Sampel

Alat: Wajan, kompor, sotel, dan serok.
Bahan: Minyak goreng kemasan $2 \mathrm{~L}$, lele 100-120 gram/ekor, bawang putih, ketumbar, dan garam.

\section{Alat dan Bahan Analisis Angka Asam}

Alat: Erlenmeyer $250 \mathrm{ml}$, buret, statif, dan klem

Bahan: Sampel, alkohol 95\%, indikator fenolfatelin, dan $\mathrm{NaOH} 0,1 \mathrm{~N}$

\section{Alat dan Bahan Analisis Angka} Peroksida

Alat : Erlenmeyer $250 \mathrm{ml}$, buret, corong, statif, klem, gelas ukur, gelas beker, dan timbangan digital.

Bahan : Sampel, asam asetat glacial, klorofom, KI, aquades $\mathrm{Na}_{2} \mathrm{~S}_{2} \mathrm{O}_{3} 0,1 \mathrm{~N}$, dan larutan pati $1 \%$.

\section{Prosedur Penelitian}

Ikan yang digunakan dalam penelitian ini yaitu ikan lele dengan penambahan bumbu bawang putih, ketumbar dan garam, selanjutnya bumbu dicampurkan dengan lele lalu dilakukan penggorengan. Berat lele yang digunakan 100-120 gram per ekor, dalam sekali menggoreng menggunakan tiga ekor lele. Bumbu yang digunakan untuk 18 ekor lele seberat 100 gram bumbu yang terdiri dari bawang putih, ketumbar dan garam.

Deep frying merupakan metode penggorengan yang digunakan dalam penelitian ini. Cara penggorengan ikan lele diawali dengan memanaskan minyak goreng hingga mencapai suhu $150-165^{\circ} \mathrm{C}$. Lele dimasukkan ke dalam wajan berisi minyak panas, sampai semua bagian ikan lele terendam dalam minyak. Lele digoreng hingga matang. Minyak yang digunakan pada hari pertama sebanyak dua liter dan berat lele 100 gram per ekor, hari kedua menggunakan lele dengan berat 100 gram per ekor dan minyak sebanyak $1850 \mathrm{ml}$, pada penggorengan hari ketiga menggunakan lele dengan berat 120 gram per ekor dan minyak sebanyak $1650 \mathrm{ml}$, sekali menggoreng 
menggunakan tiga ekor lele, dalam sehari sebanyak tiga kali penggorengan. Minyak sisa penggorengan hari pertama, disimpan di dalam wadah terbuka dan dalam suhu ruang selama satu hari. Minyak digunakan kembali pada hari berikutnya, untuk menggoreng ikan lele pada tahap penggorengan kedua dan seterusnya sampai penggorengan ketiga.

Sampel diambil sebanyak 50 gram setelah dilakukan penggorengan pada hari pertama dan dimasukkan kedalam botol kaca kemudian disimpan dalam suhu kulkas sebagai sampel pertama untuk dianalisis. Minyak sisa penggorengan hari pertama disimpan dalam wadah terbuka dan dalam suhu ruang selama satu hari, kemudian diukur dan digunakan untuk menggoreng lele pada penggorengan hari kedua. Setelah penggorengan hari kedua sampel diambil lagi sebanyak 50 gram lalu dimasukkan kedalam botol kaca kemudian disimpan dalam suhu kulkas sebagai sampel kedua untuk dianalisis. Minyak sisa penggorengan hari kedua disimpan dalam wadah terbuka dan dalam suhu ruang selama satu hari, kemudian diukur volume nya dan digunakan untuk menggoreng lele pada penggoengan hari ketiga.Setelah penggorengan hari ketiga sampel diambil lagi sebanyak 50 gram lalu dimasukkan kedalam botol kaca kemudian disimpan dalam suhu kulkas sebagai sampel ketiga untuk dianalisis.

Analisis angka asam dan angka peroksida dilaksanakan sesuai dengan SNI 3741:2013. Analisis angka asam dimuai dengan menimbang 10-50 g ke dalam erlenmeyer, selanjutnya dilarutkan dengan $50 \mathrm{ml}$ alkohol $95 \%$ netral kemudian dititrasi dengan $0,1 \mathrm{~N} \mathrm{NaOH}$ ditambahkan phenolphtalein (PP) sebagai indikator. Larutan dititrasi sampai terbentuk warna merah muda dan dicatat volume nya serta dihitung kadar angka asam.

Analisis angka peroksida dilakukan dengan menimbang $(5 \pm 0,05) \mathrm{g}$ minyak ke dalam erlenmeyer $250 \mathrm{ml}$, kemudian ditambahkan $30 \mathrm{ml}$ larutan asam asetatkhlorofom (3:2), erlenmeyer ditutup dan diaduk hingga larutan homogen. Sebanyak 0,5 ml larutan kalium iodida jenuh ditambahkan dan dikocok selama 1 menit, lalu ditambahkan $30 \mathrm{ml}$ aquades dan selanjutnya erlenmeyer ditutup. Larutan kemudian dikocok dan dititrasi dengan larutan natrium tiosulfat $0,1 \mathrm{~N}$ hingga warna kuning hampir hilang, kemudian ditambahkan $0,5 \mathrm{ml}$ larutan pati $1 \%$, lalu dikocok sampai biru hilang. Selanjutnya, dihitung angka peroksida.

\section{HASIL DAN PEMBAHASAN}

\section{Angka Asam}

Angka asam menurut Kusnandar (2010) digunakan untuk mengukur jumlah asam lemak bebas (FFA) yang terdapat dalam minyak goreng. Minyak goreng dapat terhidrolisis yang disebabkan adanya air menjadi gliserol dan asam lemak. Reaksi ini dipercepat oleh basa, asam dan enzim. Hidrolisis sangat menurunkan mutu minyak goreng. Minyak yang telah terhidrolisis menyebabkan bahan-bahan yang digoreng menjadi coklat dan lebih banyak menyerap minyak (Winarno, 2004).

Angka asam pada penelitian terus mengalami peningkatan secara statistik sesuai dengan meningkatnya frekuensi penggorengan. Adapun peningkatan jumlah angka asam pada setiap frekuensi penggorengan terdapat pada Gambar 10. Peningkatan jumlah angka asam ini sesuai dengan penelitian Laelia dan Kurnia (2019) yang menyatakan angka asam pada minyak sawit dengan produk ikan asin terus mengalami peningkatan pada setiap frekuensi penggorengan dan masih dalam batas standar SNI yang telah ditentukan. Minyak goreng baru digunakan sebagai kontrol untuk melihat apakah terdapat angka asam sebelum digunakan untuk menggoreng. Angka asam pada ketiga 
frekuensi penggorengan masih dalam batas standar yang telah ditetapkan dalam SNI 3741:2013 yaitu maksimal 0,6 mg $\mathrm{KOH} / \mathrm{g}$.

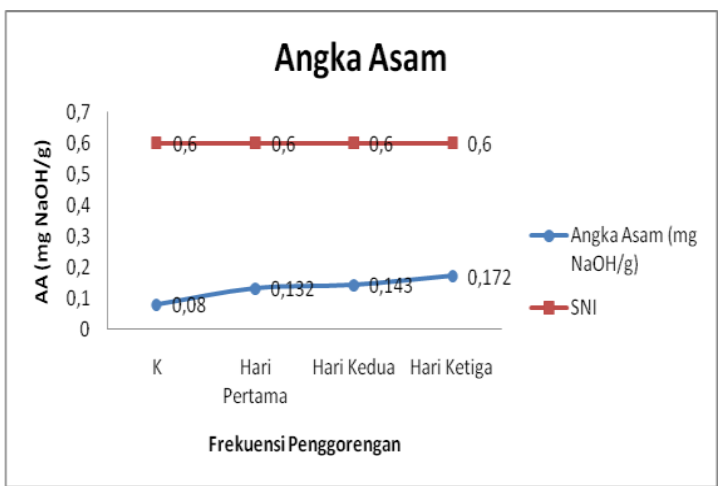

Gambar 10. Grafik Nilai Angka Asam pada Minyak Hasil Penggorengan Lele

Hasil uji statistik dari angka asam pada minyak hasil penggorengan lele terdapat pada Tabel 2. Hasil uji One Way Anova diperoleh nilai sig 0,000 $(p<0,05)$. Hal ini menunjukkan bahwa terdapat perbedaan yang nyata terhadap angka asam pada minyak hasil penggorengan lele menggunakan tiga perbedaan frekuensi penggorengan.

Hasil analisis dengan uji Duncan Multiple Range Test (DMRT) menunjukkan bahwa frekuensi penggorengan berpengaruh terhadap angka asam. Minyak hasil penggorengan hari pertama tidak memiliki perbedaan angka asam yang signifikan dengan penggorengan hari kedua. Menurut Ketaren (2005) Angka asam terbentuk karena adanya reaksi hidrolisis, air dan uap air akan menghidrolisis trigliserida pada suhu tinggi sehingga menghasilkan monogliserida, digliserida, gliserol dan asam lemak bebas. Akibat dari reaksi hidrolisis adalah bau tengik pada minyak tersebut, meningkatnya angka asam tidak hanya terjadi selama pengolahan saja melainkan pada penyimpanan (Kusnandar, 2010). Reaksi oksidasi dimulai dengan pembentukan angka peroksida dan hidroperoksida. Selanjutnya asam-asam lemak akan terurai disertai dengan konversi hidroperoksida menjadi aldehida dan keton serta asam-asam lemak bebas (Ketaren, 2005). Proses oksidasi berlangsung dengan terabstraksinya ion hidrogen dari asam lemak bebas yang terkandung di dalam minyak. Ikatan tersebut akan digantikan dengan oksigen dan membentuk senyawa alkil radikal, yang kemudian bereaksi lebih lanjut menjadi senyawa peroksida radikal. Hal tersebut dapat ditunjukkan dengan munculnya bilangan peroksida dalam minyak. Sedangkan penggorengan hari kedua memiliki perbedaan yang signifikan dengan penggorengan hari ketiga.

Tabel 2. Angka Asam pada Minyak Hasil Penggorengan Lele

\begin{tabular}{|c|c|}
\hline Frekuensi Penggorengan & Angka Asam \\
\hline Kontrol & $0,080 \pm 0,000^{a}$ \\
\hline Penggorengan hari pertama & $0,132 \pm 0,005^{\mathrm{b}}$ \\
\hline Penggorengan hari kedua & $0,143 \pm 0,004^{b}$ \\
\hline Penggorengan hari ketiga & $0,172 \pm 0,005^{\mathrm{c}}$ \\
\hline$p$ & $\mathbf{0 , 0 0 0}$ \\
\hline
\end{tabular}

Keterangan: notasi huruf yang berbeda menunjukkan beda nyata pada hasil analisis Duncan Multiple Range Test (DMRT)

\section{Angka Peroksida}

Salah satu parameter penurunan mutu minyak goreng adalah angka peroksida. Menurut Ketaren (2005), proses oksidasi berlangsung bila terjadi kontak minyak dengan oksigen yang mengakibatkan terbentuknya peroksida dan hidroperoksida kemudian selanjutnya terurainya asam-asam lemak disertai konversi hidroperoksida menjadi aldehid dan keton serta asam-asam lemak bebas. Kenaikan angka peroksida terjadi karena minyak mengalami reaksi dengan oksigen pada ikatan rangkap dan terjadi reaksi berantai yang terus-menerus menyediakan radikal bebas yang menghasilkan peroksida (Gunawan dkk., 2003).

Angka peroksida pada minyak goreng dengan tiga frekuensi penggorengan menunjukkan adanya 
perubahan yang signifikan secara statistik, hal ini sesuai dengan penelitian sebelumnya. Sama halnya dengan angka asam, seiring dengan bertambahnya frekuensi penggorengan, angka peroksida terus mengalami peningkatan. Adapun peningkatan jumlah angka peroksida pada setiap frekuensi penggorengan dapat dilihat pada Gambar 11. Minyak goreng baru digunakan sebagai kontrol untuk melihat apakah terdapat angka asam sebelum digunakan untuk menggoreng.

Gambar 11. menunjukkan bahwa angka peroksida pada minyak hasil penggorengan lele setelah digunakan untuk penggorengan hari pertama hingga hari ketiga terus mengalami peningkatan. Dari ketiga frekuensi penggorengan tersebut, angka peroksida minyak setelah penggorengan hari pertama sampai penggorengan hari ketiga masih berada dalam batas standar yang telah ditetapkan dalam SNI 3741:2013 yaitu maksimal 10 mek $\mathrm{O}_{2} / \mathrm{kg}$. Berbeda halnya dengan penelitian Laelia dan Kurnia (2019) yang menunjukkan pada penggorengan pertama sudah mendekati batas ambang standar SNI dan setelah penggorengan kedua hingga ketiga sudah jauh diatas batas ambang SNI, hal ini menunjukkan bahwa minyak yang digunakan sudah tidak layak untuk digunakan.

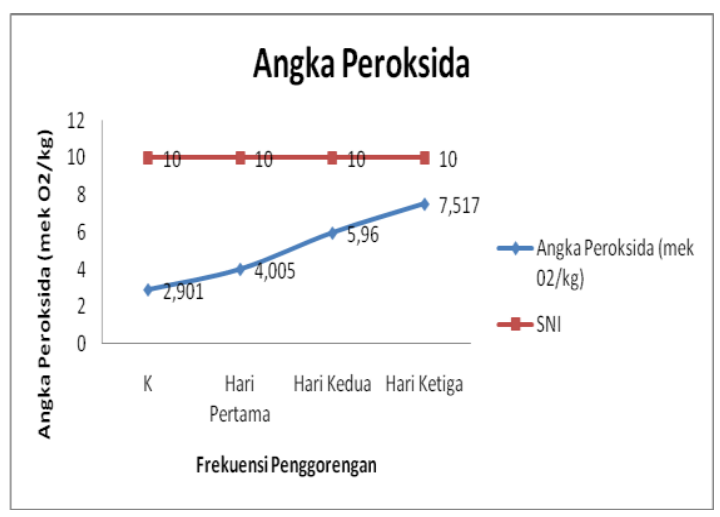

Gambar 11. Grafik Nilai Angka Peroksida Minyak Hasil Penggorengan Lele
Hasil uji statistik angka peroksida pada minyak hasil penggorengan lele dapat dilihat pada Tabel 3. Berdasarkan uji One Way Anova, terdapat perbedaan yang signifikan pada angka peroksida dari ketiga frekuensi penggorengan sig 0,000 $(p<0,05)$.

Hasil analisis Duncan Multiple Range Test (DMRT) menunjukkan bahwa frekuensi penggorengan berpengaruh terhadap kenaikan angka peroksida. Penggorengan hari pertama memiliki perbedaan yang signifikan dengan penggorengan hari kedua, dan penggorengan hari kedua memilki perbedaan yang signifikan dengan penggorengan hari ketiga.

Tabel 3. Angka Peroksida pada Minyak Hasil Penggorengan Lele

\begin{tabular}{l|l}
\hline Frekuensi Penggorengan & Angka Peroksida \\
\hline Kontrol & $2,901 \pm 0,040^{\mathrm{a}}$ \\
Penggorengan Ketiga & $4,004 \pm 0,030^{\mathrm{b}}$ \\
Penggorengan Keenam & $5,930 \pm 0,240^{\mathrm{c}}$ \\
Penggorengan Kesembilan & $7,516 \pm 0,068^{\mathrm{d}}$ \\
\hline \multicolumn{1}{c}{$\boldsymbol{p}$} & $\mathbf{0 , 0 0 0}$ \\
\hline
\end{tabular}

Keterangan: notasi huruf yang berbeda menunjukkan beda nyata pada hasil analisis Duncan Multiple Range Test (DMRT)

Reaksi oksidasi terjadi ketika adanya kontak dengan oksigen (Ketaren, 2008). Selain pada saat penggorengan, proses oksidasi juga terjadi pada saat penyimpanan. Proses penyimpanan dalam penelitian ini menggunakan wadah terbuka dalam suhu ruang. Minyak yang dibiarkan disimpan dalam wadah terbuka, memungkinkan terjadinya kontak dengan oksigen sehingga dapat menyebabkan pecahnya trigliserida menjadi gliserol, asam lemak bebas dan terbentuknya angka peroksida (Wijana dkk., 2005). Proses oksidasi berlangsung dengan terabstraksinya ion hidrogen dari asam lemak bebas yang terkandung di dalam minyak. Ikan tersebut akan digantikan dengan oksigen dan membentuk senyawa 
alkil radikal, yang kemudian bereaksi lebih lanjut menjadi senyawa peroksida radikal. Hal tersebut dapat ditunjukkan dengan munculnya bilangan peroksida dalam minyak.

Hasil pengukuran angka peroksida memberikan gambaran secara langsung mengenai tingkat oksidasi yang terjadi pada asam lemak. Semakin besar kadar angka peroksida suatu asam lemak, maka semakin besar tingkat oksidasinya. Akan tetapi, kadar angka peroksida tidak dapat dijadikan acuan tingkat oksidasi dari asam lemak, karena angka peroksida mudah terdegradasi pada oksidasi tahap akhir atau terminasi (Rauf, 2015).

\section{KESIMPULAN}

Angka asam minyak jelantah dengan angka tertinggi yaitu $0,172 \mathrm{mg}$ $\mathrm{NaOH} / \mathrm{g}$ setelah penggorengan hari ketiga. Analisis statistik menunjukkan data angka asam yang diperoleh berbeda nyata. Angka peroksida minyak jelantah dengan angka tertinggi yaitu 7,517 mek $\mathrm{O}_{2} / \mathrm{kg}$ pada penggoengan hari ketiga. Analisis statistik menunjukkan data angka peroksida yang diperoleh berbeda nyata.

\section{DAFTAR PUSTAKA}

Aminah, S. (2010). Bilangan Peroksida Minyak Goreng Curah dan Sifat Organoleptik Tempe Pada Pengulangan Penggorengan. Jurnal Pangan dan Gizi Universitas Muhammadiyah Semarang.Vol 1, No 1: 7-14

[Ditjenbun] Direktorat Jenderal Perkebunan Kementrian Pertanian. (2014). Pertumbuhan Areal Kelapa Sawit Meningkat. http://ditjenbun.pertanian.go.id/berita-362pertumbuhan-areal-kelapa-sawit-meningkat.html. [10September 2019].

Ericson, M. C. (2002). Lipid oxidantion of muscle foods, in: Food lipids: chemistry, nutrition, and biotechnology. 365-412.

Fauzi, N. 2013. Pasti! Panen Lele. Sahabat. Klaten.

Gunawan., Triatmo, M., dan Rahayu, A. (2003). Analisis Pangan : Penentuan Angka Peroksida dan Asam Lemak Bebas Pada Minyak Kedelai dengan Variasi Menggoreng. JSKA. Vol.VI.No.3.Tahun.2003.

Hendriana, A. (2010). Pembesaran Lele di Kolam Terpal. Jakarta. Penebar Swadaya.

Herlina, N., dan Ginting MHS. (2002). Lemak dan Minyak. Medan: Universitas Sumatera Utara.

Ketaren, S. (2005). Minyak dan Lemak Pangan. Jakarta: Penerbit: Universitas Indonesia. Halaman 284.

Ketaren, S. (2008). Minyak dan Lemak Pangan. Cetakan Pertama. Jakarta: Universitas Indonesia Pers.

Ketaren, S. (2012). Pengantar Teknologi Minyak dan Lemak Pangan. UI-Press, Jakarta.

Kusnandar, F. (2010). Kimia Pangan Komponen Makro. Penerbit Dian Rakyat. Jakarta.

[KKP] Kementerian Kelautan dan Perikanan Republik Indonesia. (2012). Keputusan Menteri Kelautan dan Perikanan Republik Indonesia Nomor Kep.47/Men/2012 tentang Pelepasan Nila merah nilasa. Kementrian Kelautan dan Perikanan. Jakarta

Laelia, Rahma dan Pramudia Kurnia. (2019). Pengaruh Frekuensi Penggorengan Terhadap Angka Asam dan Anga Peroksida Pada Berbagai Jenis Minyak. Jurnal Ilmu Gizi Indonesia. Vol 3. No. 1, 23-34

Rauf, Rusdin. (2015). Kimia Pangan. ANDI. Yogyakarta. 
Raharjo, S., (2006). Kerusakan Oksidatif pada Makanan. Gadjah Mada University Press. Yogyakarta

Saparinto, C. (2013). Budidaya Ikan Lele di Lahan Sempit. Penebar Swadaya. Jakarta.

Sari, Mukti Arta. (2016). Analisis Permintaan Ikan Lele (Clarias sp) Oleh Pedagang Pecel Lele di Kota Bandar Lampung.Skripsi. Fakultas Pertanian Universitas Lampung. Bandar Lampung.

[SNI] Standar Nasional Indonesia. Minyak Goreng. Badan Standarisasi Nasional. 3741:2013. ICS:67.200.10. Diakses dari https://dokumen.tips/documents/sni-37412013-minyak-goreng-558463df91cf6.html

Sudarmadji, S., B. Haryono dan Suhardi. (2007). Prosedur Analisa Untuk Bahan Makanan dan Pertanian. Liberty. Yogyakarta.

Wijana, S., Arif, H., dan Nur, H. 2005. Teknologi Pangan: Mengolah Minyak Goreng Bekas. Trubus Agrisarana. Surabaya.

Winarno, F.G. (2004). Kimia Pangan dan Gizi. PT Gramedia Pustaka Utama. Jakarta.

Zulkifli, Mochamad dan Teti Estiasih. (2014). Sabun Dari Distilat Asam Lemak Minyak Sawit: Kajian Pustaka. Jurnal Pangan dan Agroindustri Vol. 2 No 4 p.170-177. 